\title{
Implications of Agricultural Gypsum Doses in Physical-Hydric Attributes of a Typic Haplortox and on Root Growth and Soybean Productivity
}

\author{
Francisco de Assis Guedes Júnior ${ }^{1}$, Deonir Secco ${ }^{1}$, Luiz Antônio Zanão Júnior ${ }^{2}$, Luciene Kazue Tokura ${ }^{1}$ \\ \& Marcos Felipe Leal Martins ${ }^{1}$ \\ ${ }^{1}$ Graduation Program, Master's in Engineering of Energy in Agriculture, State University of West Paraná, \\ Cascavel, Paraná, Brazil \\ ${ }^{2}$ Agronomic Institute of Paraná, Santa Tereza do Oeste, Paraná, Brazil \\ Correspondence: Luciene Kazue Tokura, Graduation Program, Master's in Engineering of Energy in Agriculture, \\ State University of West Paraná, Rua Universitária, 2069-Jardim Universitário, CEP: 85819-110, Cascavel, \\ Paraná, Brazil. Tel: 55-453-220-3151. E-mail: lucienetokura@gmail.com
}

Received: December 22, 2018

Accepted: January 30, 2019

Online Published: March 15, 2019

doi:10.5539/jas.v11n4p549

URL: https://doi.org/10.5539/jas.v11n4p549

\begin{abstract}
The response to agricultural gypsum, as a conditioner of the root environment in depth, has been observed for most annual crops. These responses are attributed to the better distribution of roots of the crops in depth in the soil by the reduction of chemical impediments, caused by the exchangeable aluminum and calcium deficiency in these layers, which allows to the plants the use of greater volume of water when they occur summer. In this way, the objective of this study was to evaluate the effects of gypsum doses on physical-hydric attributes, root growth and soybean productivity. The experiment was conducted at the Agronomic Institute of Paraná (IAPAR) in Santa Tereza do Oeste-PR. The soil was classified as Typic Haplortox. Five doses of agricultural gypsum were evaluated: $0 ; 3 ; 6 ; 9$ and $12 \mathrm{t} \mathrm{ha}^{-1}$, in outline randomized block design with six repetitions. Soil density, total porosity, macroporosity, microporosity and saturated hydraulic conductivity were evaluated at layers of $0.0-0.1$; $0.1-0.2$ and $0.2-0.3 \mathrm{~m}$. Soybean productivity and root growth were also evaluated. Data were submitted to regression analysis. The physical attributes soil density, macroporosity and saturated hydraulic conductivity did not differ significantly with the application of the gypsum doses in the 0.0-0.1 and 0.2-0.3 m layers. However, in the 0.1-0.2 $\mathrm{m}$ layer, due to pressures imposed by the machines and agricultural implements deforming the soil, there were significant differences in the physical attributes of the density, macroporosity and saturated hydraulic conductivity. There was no significant difference in grain productivity and root growth of soybean.
\end{abstract}

Keywords: Aluminum, Glycine max, soil structure

\section{Introduction}

In the western region of Paraná, soybeans stand out in the economic sector and a good part of the agricultural revenue in the region comes from the commerce of this culture. The technology of using agricultural gypsum has been an important management strategy to aid in the production of grain, mainly as soil conditioner for the soybean crop. This technology proves to be feasible both socially and environmentally, and it also allows in the field income generation in the rural property, reduction of agrochemicals, agricultural inputs that allied with the conservationist practice of the soil as the no-tillage propitiates improvement in the quality of the soil.

Agricultural gypsum is composed basically of calcium and sulfur and acts as a soil conditioner. High solubility, when applied to the soil, reduces aluminum saturation in depth, and translocate nutrients from the superficial layers to the subsurface, mainly calcium, thus allowing greater efficiency and area explored by the roots (Leite et al., 2007; Zambrosi, Alleoni, \& Caires, 2007b; Broch et al., 2008; Raij, 2008; Soratto \& Crusciol, 2008b; Neiset al., 2010; Broch et al., 2011; Zandoná et al., 2015). Gypsum could be applied to acid soils to complement limestone to favor the root system growth and development in depth, because of its soil conditioning effects (Zhang, \& Norton, 2002; Meurer, Rhenheimer, \& Bissani, 2004).

According to Coleman and Thomas (1967), agricultural production is, for the most part, limited by diverse factors present in Brazilian soils, mainly in the West of Paraná, by the effect of soil acidity and, consequently, in 
certain areas where they predominate the red latosol, by the toxicity caused by $\mathrm{Al}^{3+}$ and $\mathrm{Mn}^{2+}$ and low saturation by bases.

According to Carvalho and Raij (1997), Soratto and Crusciol (2008a), and Carducci et al. (2015), it is large the amount of information on the agricultural gypsum effect to improve the radicle environment of plants, due to the calcium movement to subsurface layers of the soil or decrease in the toxic effects of high aluminum contents. Still for Soratto and Crusciol (2008b), subsurface layers with low calcium levels and/or high exchangeable aluminum contents may cause decrease of harvests, especially in regions prone to low rainfall (dry spell), as they lead to less root system deepening, resulting in less soil volume explored by the roots, and in turn, less nutrients and water available to the plant.

Within this optics to Raij (2008), the activity of free $\mathrm{Al}^{3+}$ in the solution is a more consistent indicator of aluminum toxicity in soil solutions. Thus, the Ca displacement in the soil profile is much greater when gypsum is the source $\left(\mathrm{CaSO}_{4} \cdot 2 \mathrm{H}_{2} \mathrm{O}\right) . \mathrm{SO}_{4}{ }^{2-}$ anion that is part of the agricultural gypsum formula is important in reducing $\mathrm{Al}^{3+}$ activity, which helps root development (Zambrosi, Alleoni, \& Caires, 2007a; Nora et al., 2014). However, the incorrect use of plaster can cause chemical imbalance to the soil, causing long-term damage (Pauletti et al., 2014). According to Costa et al. (2007), the reduction of soil density (Sd) can be attributed to the fact that the gypsum aggregation action is due to the supply of cations that possibly neutralize part of the negative charges occurring in the medium.

For Machado and Freitas (2004) and Sanchez et al. (2014), the maintaining soil with good fertility, physical, chemical, biological and water properties can provide good crop productivity.

In western Paraná, soybean stands out in the economy, with much of the region's income coming from the culture (CONAB, 2017). The technology of the use of agricultural gypsum has been an important handling strategy to aid in grain production, mainly as soil conditioner for the soybean crop (Fukushima, 2001).

Therefore, this study aimed to evaluate the effect of agricultural gypsum doses on soil physical attributes, root growth and soybean productivity in a no-till system in west Paraná.

\section{Material and Methods}

\subsection{Location of the Experimental Area}

The experimental area is in the municipality of Santa Tereza do Oeste-PR, located on the third Parana plateau at latitude $25^{\circ} 08^{\prime}$ (South) and longitude $53^{\circ} 58^{\prime}$ (West), with an average elevation of $750 \mathrm{~m}$. The experiment occurred in a Typic Haplortox, clayey texture, basalt substrate, smooth-wavy relief (EMBRAPA, 2013), cultivated under no-tillage system (NTS) for more than eighteen years. The soil is clayey textural class, with $29 \%$ sand, $11 \%$ silt and $60 \%$ clay.

Table 1 shows the soil chemical determinations, collected in 2013, prior to the experiment, that is, before the application of the agricultural gypsum. Fifteen subsamples were collected in the experiment area.

Table 1. Content of $\mathrm{Al}, \mathrm{Ca}, \mathrm{Mg}, \mathrm{K}$, base saturation (V) and aluminum (m) at different soil layers

\begin{tabular}{|c|c|c|c|c|c|c|}
\hline Layers & $\mathrm{Al}^{3+}$ & $\mathrm{Ca}^{2+}$ & $\mathrm{Mg}^{2+}$ & $\mathrm{K}^{+}$ & V & $\mathrm{m}$ \\
\hline ----------- cm ----------- & \multicolumn{4}{|c|}{ 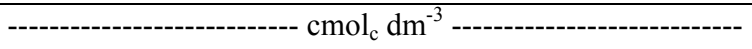 } & \multicolumn{2}{|c|}{----------------- \% ------------------ } \\
\hline $0-10$ & 0.68 & 4.20 & 1.03 & 0.25 & 36.09 & 11.21 \\
\hline $10-20$ & 1.20 & 3.09 & 0.92 & 0.22 & 28.31 & 23.36 \\
\hline $20-40$ & 1.33 & 2.14 & 0.91 & 0.19 & 23.28 & 30.62 \\
\hline $40-60$ & 1.03 & 1.97 & 0.99 & 0.18 & 25.48 & 25.53 \\
\hline $60-80$ & 0.36 & 1.82 & 1.30 & 0.19 & 33.83 & 9.37 \\
\hline
\end{tabular}

According to Köppen's classification, the climatic characteristic of the region is mesothermal humid subtropical, $\mathrm{Cfa}$, with average in the hottest month above $22{ }^{\circ} \mathrm{C}$ and in the coldest month below $18{ }^{\circ} \mathrm{C}$, with no defined dry season, hot summer and frost less frequently. Rainfall is abundant and well distributed throughout the year; the annual averages are between 1,800 and 2,000 $\mathrm{mm}$ (IAPAR, 2000). During the whole cycle, the rainfall volume was around $1,118 \mathrm{~mm}$ and the average temperature was $22.61{ }^{\circ} \mathrm{C}$. Figure 1 shows the rainfall data, temperature and evapotranspiration evaluated every 15 days during soybean cycle. 


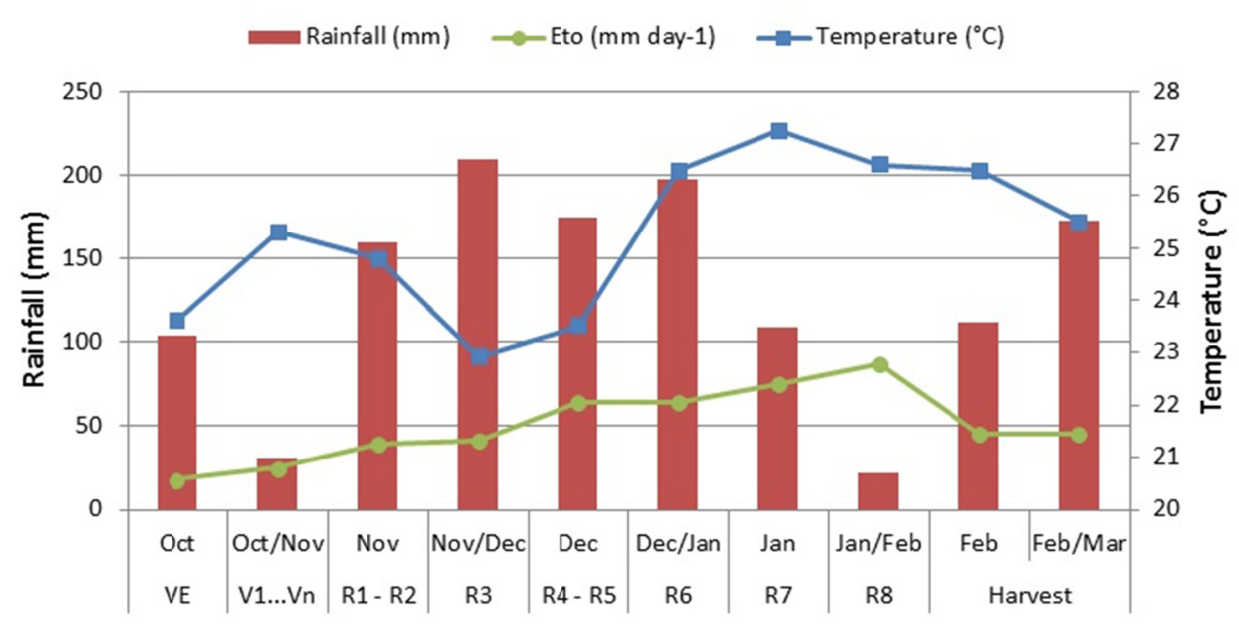

Vegetative and reproductive stages of soybean plants

Figure 1. Rainfall, temperature and evapotranspiration (ETc) of the crop in the soybean vegetative cycle from October 2015 to February 2016 in the western region-PR

\subsection{Characterization of the Treatments}

Initially, the area was cultivated with no-tillage system with winter and spring coverage; later, gypsum was applied to the soil surface (December 2013), to the following late growing season of corn (February 2014), beans in sequence (October 2014), late growing season of maize (February 2015), and finally soybean (October 2015) when the experiment started.

The in outline was randomized block design with six repetitions. The plots $(5 \times 6 \mathrm{~m})$ received the treatments that consisted of five doses of agricultural gypsum $\left(0,3,6,9,12 \mathrm{t} \mathrm{ha}^{-1}\right)$ in a randomized block design with six replicates. Agricultural gypsum dose was $3 \mathrm{t} \mathrm{ha}^{-1}\left(60 \%\right.$ clay, $\left.50 \mathrm{~kg}=3.0 \mathrm{tha}^{-1}\right)$. From the $3.0 \mathrm{t} \mathrm{ha}^{-1}$ value, the other gypsum doses were defined: zero, once, twice, three and four times the recommended dose, applied manually depending on the soil clay content Embrapa's recommendation EMBRAPA (2005).

The cultivar BMX Apollo was utilized for the experiment and treated with insecticide TS Cruieser 350 FS 200 $\mathrm{mL} 100 \mathrm{~kg}$ seeds $^{-1}$, and fungicides Vitavax-Thiram $300 \mathrm{~mL} 100 \mathrm{~kg}$ of seeds ${ }^{-1}$. Soybean sowing occurred on October 5, 2015, with $0.45 \mathrm{~m}$ spaced, 16 seeds per meter. The control of weeds, pests and diseases occurred according to the crop need.

\subsection{Agronomic Characteristics Evaluated}

During August 2015, the area remained in fallow to collect the soil physical samples. To analyze soil density, soil microporosity, soil macroporosity, total porosity and saturated hydraulic conductivity, trenches were opened in each experimental unit and samples were taken from undisturbed samples on stainless-steel volumetric rings with a $98 \mathrm{~cm}^{3}$ volume $(5 \mathrm{~cm}$ diameter and $5 \mathrm{~cm}$ height), in three soil layers $(0.0-0.1 ; 0.1-0.2$ and $0.2-0.3 \mathrm{~m})$, with the aid of pedological hammer and soil extractor.

Soil volume in the samples was adjusted properly and saturated in water for 24 hours in a tray with a water level at $2 / 3$ of their height. Saturated samples were weighed and placed in a 0.6 m.c.a sand column and remained there for two days, draining the water in the macropores. After that was determined the saturated hydraulic conductivity $\left(\mathrm{K}_{\theta \mathrm{S}}\right)$ in a constant-load permeameter. The samples were again saturated for 24 hours. Afterwards, this sample was allocated to the constant-load permeameter so that it could read the collected volume as a function of time, after which the soil hydraulic conductivity was calculated, according to the methodology recommended by EMBRAPA (2011).

After the $\mathrm{K}_{\theta \mathrm{S}}$ determination, the samples were placed in an oven at $105^{\circ} \mathrm{C}$ for 48 hours to determine the dry soil mass. To calculate the soil density, the dry samples mass was divided by the volume of volumetric ring at $105^{\circ} \mathrm{C}$, according to the equation: $\mathrm{Sd}=\mathrm{Mss} / \mathrm{Tv}$, in which $\mathrm{Sd}$ is soil density and Mss, mass of the sample of dry soil at $105^{\circ} \mathrm{C}$, and $\mathrm{Tv}$ is total volume of the ring, EMBRAPA (2011). 
Calculating total soil porosity occurred with the relationship between soil density and particle density, as equation: $\mathrm{Tp}=(1-\mathrm{Sd}) / \mathrm{Pd} * 100$ in which $\mathrm{Tp}$ is total porosity, measured in $\left(\mathrm{m}^{3} \mathrm{~m}^{-3}\right)$ and $\mathrm{Sd}$ is soil density, measured in $\left(\mathrm{Mg} \mathrm{m}^{-3}\right)$ and Pd is particle density measured in $\left(\mathrm{Mg} \mathrm{m}^{-3}\right)$, EMBRAPA (2011).

Microporosity was determined using water content retained in the samples in equilibrium with the tension of 0.6 m.c.a; this tension is enough to remove the water in the macropores, and the remaining water represents the volume of micropores obtained by equation: Micro $=($ Msu-Mss $) /$ Mss $\times 100$, Micro $=$ Soil microporosity $\left(\mathrm{m}^{3}\right.$ $\left.\mathrm{m}^{-3}\right)$; Msu or Pa 0.6 m.c. $\mathrm{a}=$ soil mass after 0.6 m.c.a tension $(\mathrm{Mg})$; Mss $=$ mass of dry soil $(\mathrm{Mg})$.

Thus, with total porosity and microporosity, calculating the macroporosity was possible (Camargo et al., 2009) according to equation: Macro $=$ Pt-Micro $\left[\right.$ Macro $=$ soil macroporosity $\left(\mathrm{m}^{3} \mathrm{~m}^{-3}\right) ; \mathrm{Tp}=$ total porosity $\left(\mathrm{m}^{3} \mathrm{~m}^{-3}\right)$; Micro $=$ soil microporosity $\left(\mathrm{m}^{3} \mathrm{~m}^{-3}\right)$ ], EMBRAPA (2011).

To analyze soybean root growth, a $0.50 \times 0.50 \mathrm{~m}$, wooden grid was made with several nylon lines forming small $5 \mathrm{~cm}$ square strips on each side, which was used to estimate the root size and area. For the analysis, $1.0 \times 0.6 \mathrm{~m}$ depth trenches were opened for each treatment, where soybean roots were exposed in parallel rows by trench. Thus, the roots were exposed for evaluation, and, with the squared grid placed in front of the root, the measurements of the soybean roots were carried out, profile method (Böhm, 1979).

The soybean harvest occurred on February 10, 2016 using a combine harvester (Wintersteiger Classic $($ ) with three $0.45 \mathrm{~m}$ rows. Productivity was determined by the useful area, $30 \mathrm{~m}^{2}$, transformed in $\mathrm{kg} \mathrm{ha}^{-1}$ and corrected to $13 \%$ moisture.

\subsection{Statistical of the Data}

Data were submitted to analysis of variance and the effect of the agricultural gypsum doses evaluated by regression analysis. The model based on the coefficient significance of the adjusted regression equation as well as on the coefficient of determination $\left(\mathrm{R}^{2}\right)$ associated with each model, using the Assistat software version 7.7 beta (Silva, 2016).

\section{Results and Discussion}

The significant results with the application of the gypsum doses on the physical properties of the soil occurred only in the layers of 0.1 to $0.2 \mathrm{~m}$ for all attributes worked. These results are usually expected in this layer, due to the pressures of the machines, agricultural implements and the influence of the chemical reactions of the soil in the presence of the gypsum.

The area with the system of direct manipulation with the gypsum has contributed to the results of the processes of comparison with the root systems of the soybean crop, with the use of gypsum improved physical soil properties. When applying $3 \mathrm{tha}^{-1}$ gypsum, the best result of productivity corresponds to the recommendation of Embrapa (2015), which had a better effect. Thus, as a result, was can see Figures 2, 3 and 4 attributes. 

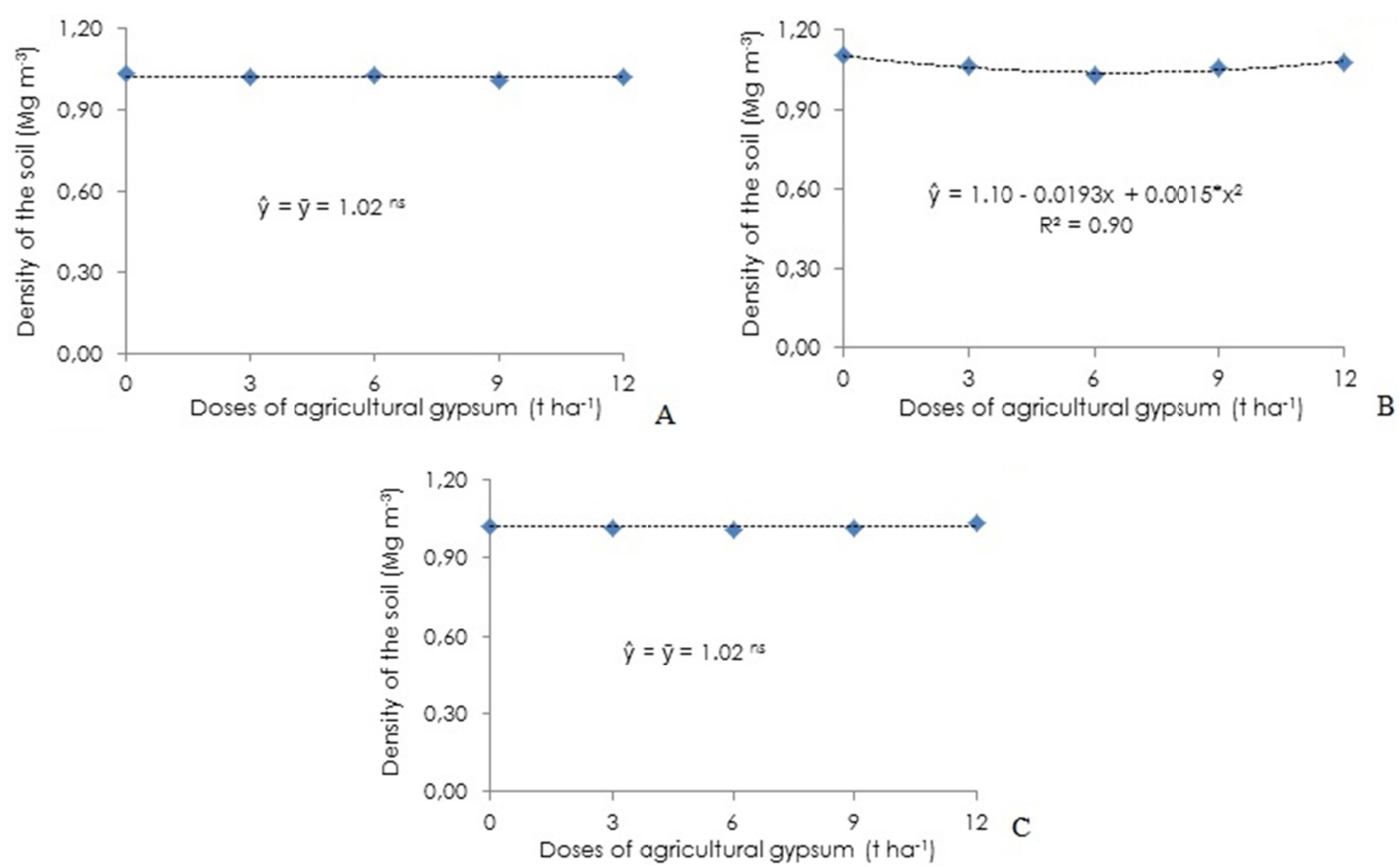

Figure 2. Density of the soil in the layers 0.0-0.1 (A), 0.1-0.2 (B) and 0.2-0.3 $\mathrm{m}(\mathrm{C})$ as a function of agricultural gypsum doses

Soil density is the property representing the soil compaction state of the soil where, generally, in areas handled with NTS and agricultural gypsum, the highest values occur in the 0.1-0.2 m layer. In addition, the pressure imposed by agricultural machines and implements on the surface soils may negatively impact the root growth of soybeans.

Soil density in the $0.0-0.1 \mathrm{~m}$ and $0.2-0.3 \mathrm{~m}$ layers did not differ significantly, whereas for the 0.1 to $0.2 \mathrm{~m}$ layer a significant difference occurred (Figure 2A, B e C). Soil density had an average value of $1.02 \mathrm{Mg} \mathrm{m}^{-3}$. Treatments on the $0.0-0.1 \mathrm{~m}$ and $0.2-0.3 \mathrm{~m}$ layers showed results close to the general average. For the $0.0-0.1 \mathrm{~m}$ layer, due to higher organic matter, root and biopor content, and because of greater soil rotation by seeder furrows, compacted layer is not formed. For the 0.1-0.2 m layer, there was a significant increase in relation to the other layers, because agricultural gypsum improved the roots of the previous crops (Figure 2B). Pressures exerted by the machines and agricultural implements that promote deformation, compaction and root debris from previous crops promote increased soil density by occupying and pressing the soil porous spaces. The $0.2-0.3 \mathrm{~m}$ layer has not changed, because the tire pressure of the agricultural machinery would not reach this layer.

According to Reichert, Reinert, and Braida (2003) the restrictive value of density for Haplortox with clay contents greater than $70 \%$ is close to $1.40 \mathrm{Mg} \mathrm{m}^{-3}$. For Reichert, Reinert, and Braida (2003) soil density values clayey soils of $1.35 \mathrm{Mg} \mathrm{m}^{-3}$ and for sandy soils of $1.55 \mathrm{Mg} \mathrm{m}^{-3}$ indicate compaction, which may hinder the root system development.

In the present study soil density values were below those reported as limiting or potentially causing root growth difficulties. These values are like those reported by Araújo, Goedert, and Pinto (2007) found value 0.84 in between $1.3 \mathrm{Mg} \mathrm{m}^{-3}$. 

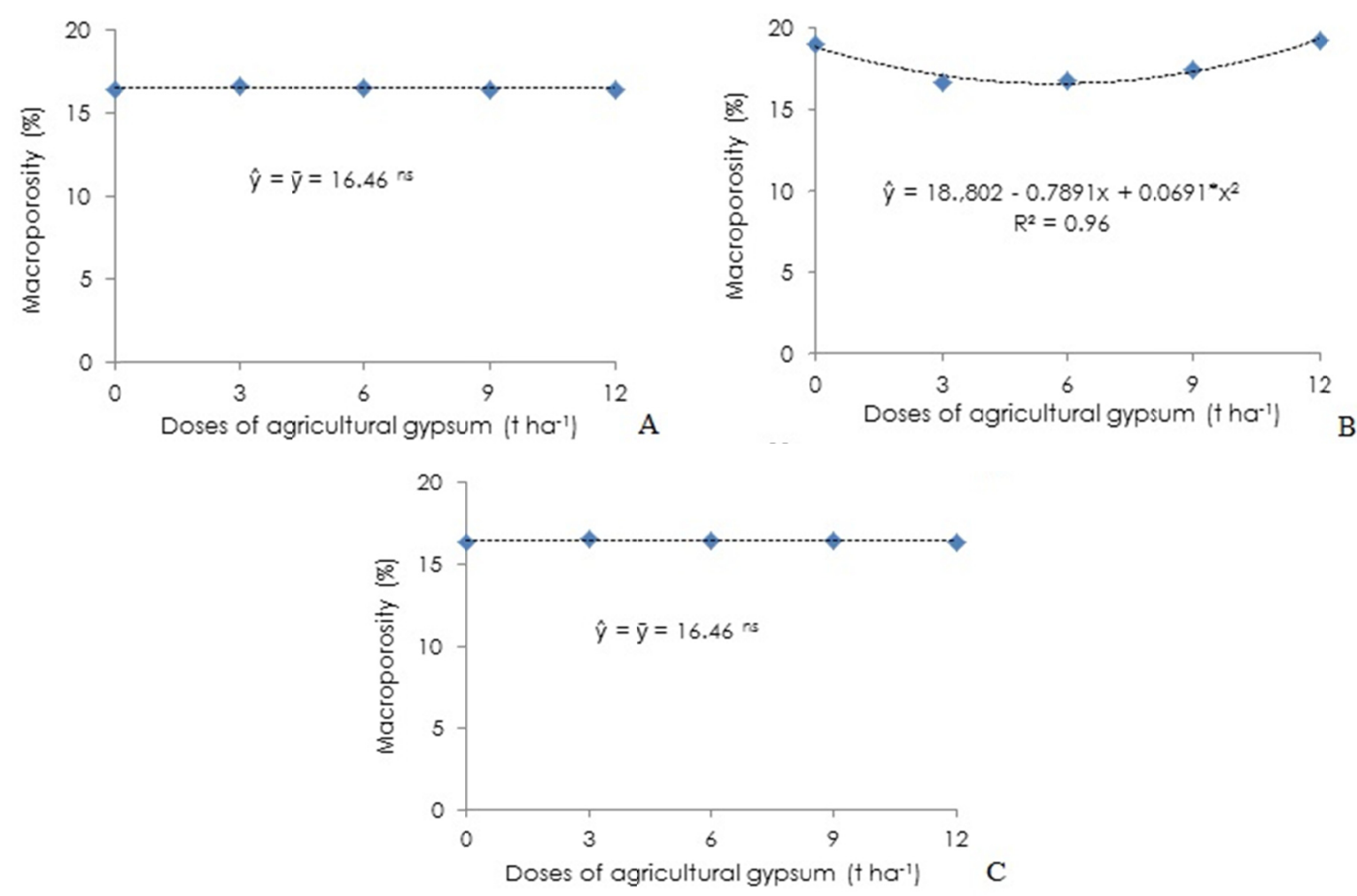

Figure 3. Macroporosity of the soil in the layers $0.0-0.1$ (A), 0.1-0.2 (B) and $0.2-0.3 \mathrm{~m}(\mathrm{C})$ as a function of agricultural gypsum doses

For soil macroporosity in the 0.0-0.1 $\mathrm{m}$ and $0.2-0.3 \mathrm{~m}$ layers there was no significant difference (Figure $3 \mathrm{~A}$ and 3C) depending on the gypsum doses. For the 0.1 to $0.2 \mathrm{~m}$ layer, significant difference occurred (Figure 3B).

In this study, the average macroporosity values were $16.46 \%$ for the $0.0-0.1 \mathrm{~m}$ layer and $15.19 \%$ for the $0.2-0.3$ $\mathrm{m}$ layer. These values were higher than those considered critical to the crop development according to Lier (2010). In the 0.1-0.2 m layer, the value was $17.79 \%$, which is above the critical value. Therefore, root growth of the previous cultures improved, which were benefited with the agricultural gypsum allowing an increase of macropores in this layer. The critical values are below 10\%, according Reichert et al. (2009).
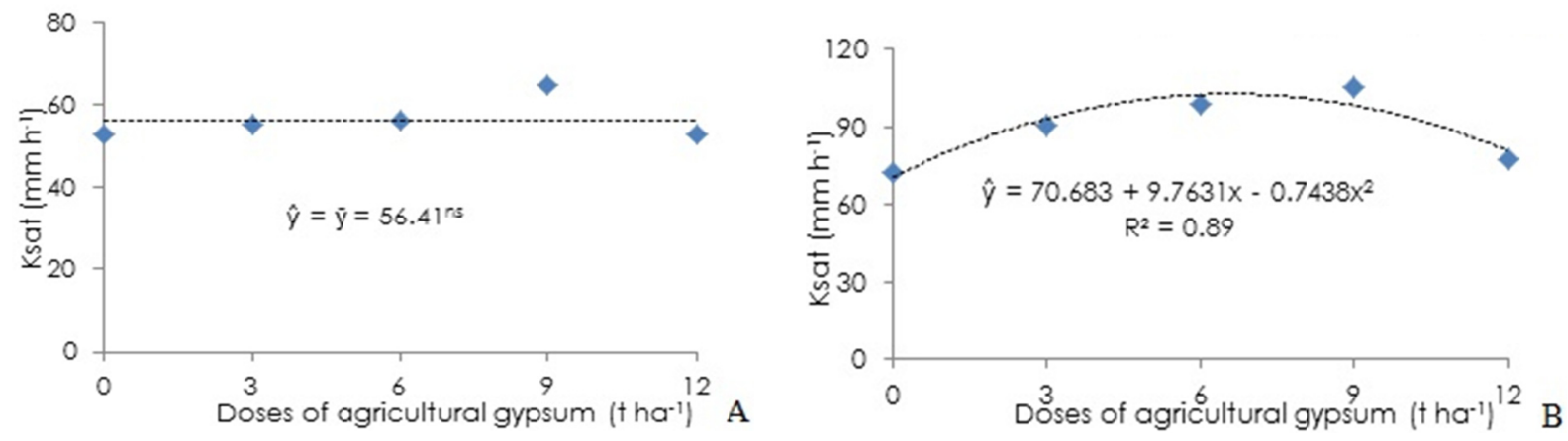


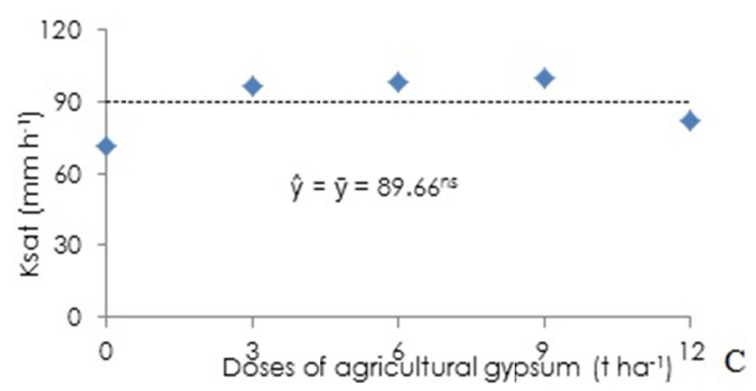

Figure 4. Soil hydraulic conductivity (Ksat) in the layers 0.0-0.1 (A), 0.1-0.2 (B) and 0.2-0.3 $\mathrm{m}$ (C) as a function of agricultural gypsum doses

According to Lier (2010), the critical value for the agricultural cultivation development is around $10 \%$ for soil macroporosity. Thus, all treatments present adequate amount of macropores (Figures 2, 3 and 4).

The saturated hydraulic conductivity in the $0.0-0.1 \mathrm{~m}$ and $0.2-0.3 \mathrm{~m}$ layers did not differ significantly. For the 0.1 to $0.2 \mathrm{~m}$ layer, the difference was significant (Figure 4B). As soil macroporosity was favored with the organic matter of the previous crop's roots in this layer, the saturated hydraulic conductivity also had a significant effect. This higher $\mathrm{K}_{\theta \mathrm{S}}$ value associates with the higher volume of macropores in this layer (Figure $4 \mathrm{C}$ ).

There is a possible tendency for saturated hydraulic conductivity $\left(\mathrm{K}_{\theta \mathrm{S}}\right)$ to increase in depth (Figure $\left.4 \mathrm{~B}\right)$. The results did not show significant differences between the 0.0-0.1 $\mathrm{m}$ and 0.2-0.3 m layers, whereas for the 0.1-0.2 $\mathrm{m}$ layer a significant difference occurred.

Regarding the root growth, a root evaluation was performed at stage R8 (full maturation) for gypsum dose responses, in which there was no positive response to vertical and lateral root growth in the application of agricultural gypsum doses in the soybean crop (Figure 5).

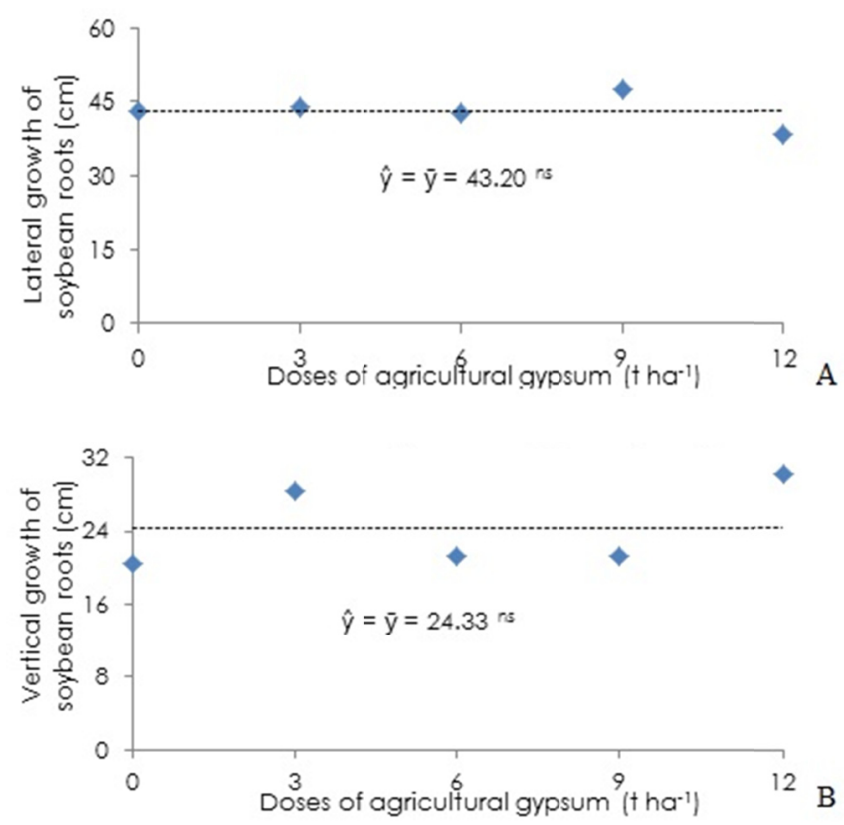

Figure 5. Lateral and vertical growth of soybean roots as a function of agricultural gypsum doses

Caires et al. (2008) explains that the absence of soybean response to gypsum application may occur because of the growth of its soybean root system, in the absence of water deficit (Figure 2), not being influenced by the reduction of Al saturation in the soil subsurface. However, according to Raij (2008), applying agricultural gypsum allows better adequate conditions to the subsoil, and thus it can reduce the soil compaction, which is usually favorable to the roots. 
In the periods between 2015 and 2016, climatic conditions allied to management practices in the no-tillage system with surface layer rich with organic matter and a year with a good rain distribution during the entire vegetative cycle, without mechanical restriction, good soil structure in satisfactory physical conditions, for having a larger number of porous spaces allowed the root system to explore the studied soil layers. Good crop development is possible with no effect on the application of the agricultural gypsum.

No significant differences between treatments for grain productivity were observed (Figure 6).

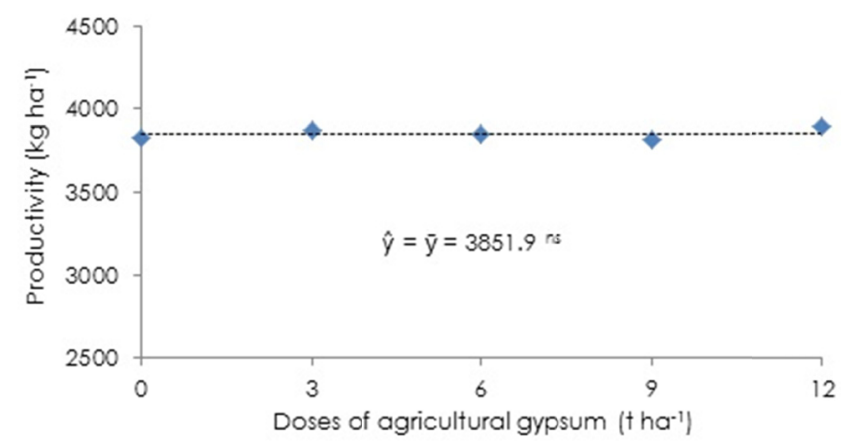

Figure 6. Grain productivity in relation to agricultural gypsum dosages applied in the soybean crop

There were probably no significant differences between the gypsum doses for the grain productivity of soybean because of climatic conditions favorable to crop development, such as good fertility and structural conditions of the soil, good rainfall distribution, and presence of organic matter under the no-tillage system.

Other authors also found no effect on grain productivity compared to gypsum doses, as in the works of Neis et al. (2010); Souza et al. (2010); Caires, Joris, and Churka (2011a); Caires et al. (2011b). There were probably no significant differences between the gypsum doses for the grain yield of soybean because of climatic conditions favorable to crop development, such as good fertility and structural conditions of the soil, good rainfall distribution (Figure 2), and presence of organic matter under the no-tillage system, as demonstrated by Rampim et al. (2011).

In an application experiment of gypsum in the soybean crop, conducted in a dystrophic Red Latosol, Cardoso, Peres and Lambert (2014) observed the absence of soybean response to gypsum application, pointing to the non-occurrence of water deficit as a limiting factor to the gypsum action for this culture.

Likewise, Caires, Joris, and Churka (2011a) did not obtain increase of grain productivity in the soybean crop when applying $9 \mathrm{t} \mathrm{ha}^{-1}$ gypsum in a dystrophic Red Latosol with clay texture, both in no-tillage system and in conventional tillage.

\section{Conclusions}

The soil density, macroporosity and saturated hydraulic conductivity did not differ significantly with the application of the gypsum doses in the 0.0-0.1 and 0.2-0.3 m layers.

In the 0.1-0.2 m layer, there were significant differences in the physical attributes of the density, macroporosity and saturated hydraulic conductivity.

There was no significant difference in grain productivity and root growth of soybean.

\section{Acknowledgements}

This study was financed in part by the Coordenação de Aperfeiçoamento de Pessoal de Nível Superior-Brasil (CAPES)-Finance Code 001.

\section{References}

Araújo, R., Goedert, W. J., \& Pinto, M. P. C. (2007). Soil quality under different uses and native Cerrado. Revista Brasileira de Ciência do Solo, 31(5), 1099-1108. https://doi.org/10.1590/S0100-06832007000500025

Böhm, W. (1979). Methods of studying root systems. Berlin: Springer-Verlag. https://doi.org/10.1007/978 $-3-642-67282-8$ 
Broch, D. L., Nolla, A., Quiqui, E. M. D., \& Possenti, J. C. (2008). Influence of Phosphorus, Limestone and Gypsum Fertilization on the Yield of the Soybean Plants Grown in no Tillage System. RECEN-Revista Ciências Exatas e Naturais, 10(2), 211-220.

Broch, D. L., Pavinato, P. S., Possentti, J. C., Martin, T. N., \& Quiqui, E. M. D. (2011). Soybean grain yield in Cerrado region influenced by Sulphur sources. Revista Ciência Agronômica, 42(3), 791-796. https://doi.org/ $10.1590 / \mathrm{S} 1806-66902011000300027$

Caires, E. F., Garbuio, F. J., Churka, S., Barth, G., \& Corrêa, J. C. L. (2008). Effects of soil acidity amelioration by surface liming on no-till corn, soybean, and wheat root growth and yield. European Journal of Agronomy, 28(1), 57-64. https://doi.org/10.1016/j.eja.2007.05.002

Caires, E. F., Joris, H. A. W., \& Churka, S. (2011a). Long-term effects of lime and gypsum additions on no-till corn and soybean yield and soil chemical properties in southern Brazil. Soil Use and Management, 27(1), 45-53. https://doi.org/10.1111/j.1475-2743.2010.00310.x

Caires, E. F., Maschietto, E. H. G., Garbuio, F. J., Churka, S., \& Joris, H. A. W. (2011b). Surface application of gypsum in low acidic Oxisol under no-till cropping system. Scientia Agricola, 68(2), 209-216. https://doi.org/10.1590/S0103-90162011000200011

Camargo, O. A., Muniz, A. C., Jorge, J. A., \& Valadares, J. M. A. S. (2009). Métodos de análise química, mineralógica e física de solos do Instituto Agronômico de Campinas. Campinas: Instituto Agronômico. Retrieved from http://www.iac.sp.gov.br/publicacoes/porassunto/pdf/Boletim106.pdf

Cardoso, J. A. E., Peres, G. C. M., \& Lambert, R. A. (2014). Gypsum and lime increase soybean and maize yield and decrease drought stress. Revista Enciclopédia Biosfera, 10(18), 1980-1987. https://doi.org/10.1590/ $1983-40632015 \mathrm{v} 4530301$

Carducci, C. E., Oliveira, G. C., Curi, N., Heck, R. J., Rossoni, D. F., Carvalho, T. S. de, \& Costa, A. L. (2015). Gypsum effects on the spatial distribution of coffee roots and the pores system in oxidic Brazilian Latosol. Soil and Tillage Research, 145, 171-180. https://doi.org/10.1016/j.still.2014.09.015

Carvalho, M. C. S., \& Raij, B. V. (1997). Calcium sulphate, phosphogypsum, and calcium carbonate in the amelioration of acid ssul sois for root growth. Plant and Soil, 192(1), 37-48. https://doi.org/10.1023/ A: 1004285113189

Coleman, N. T., \& Thomas, G. W. (1967). The basic chemistry of soil acidity. In R. W. Pearson, \& F. Adams (Eds.), Soil acidity and liming (pp. 1-41). Madison: American Society of Agronomy.

CONAB (Companhia Nacional de Abastecimento). (2017). Acompanhamento da safra brasileira de grãos (Vol. 10). Brasília, Brazil. Retrieved from https://www.conab.gov.br/index.php/institucional/publicacoes/compe ndio-de-estudos-da-conab/item/2898-compendio-de-estudos-da-conab-v-10-pordutividade-da-soja.

Costa, M. J., Rosa Junior, E. J., Rosa, Y. B. C. J., Souza, L. C. F., \& Rosa, C. B. J. (2007). Latossol chemical and physical attributes affected by tillage system and gypsum effect. Acta Scientiarum. Agronomy, 29(5), 701-708.

EMBRAPA (Empresa Brasileira de Pesquisa Agropecuária). (2011). Manual de métodos de análise de solo: Centro Nacional de Pesquisa de Solos. Rio de Janeiro: Embrapa.

EMBRAPA (Empresa Brasileira de Pesquisa Agropecuária). (2013). Sistema Brasileiro de Classificação de Solos. Centro Nacional de Pesquisa de Solos (3rd ed.). Rio de Janeiro: Embrapa.

Fukushima, D. (2001). Recent Progress in Research and Technology on Soybeans. Food Science and Technology Research, 7(1), 8-16. https://doi.org/10.3136/fstr.7.8

IAPAR (Instituto Agronômico do Paraná). (2011). Cartas Climáticas do Estado do Paraná. Londrina: IAPAR. Retrieved from http://www.iapar.br/pagina-677.html

Leite, E. M., Cavalcante, L. F., Diniz, A. A., Santos, R. V., Alves, G. S., \& Cavalcante, I. H. L. (2007). Sodicity correction of two irrigated soils in response to application of agricultural gypsum. Irriga, 12(2), 168-176. https://doi.org/10.15809/irriga.2007v12n2p168-176

Lier, Q. J. V. (2010). Física do Solo. Viçosa: Sociedade Brasileira de Ciência do Solo.

Machado, P. L. O. A., \& Freitas, P. L. (2004). No till farming in Brazil and its impact on food security and environmental quality. In R. Lal, P. Hobbs, N. Uphoff, \& D. Hansen (Eds.), Sustainable agriculture and the rice-wheat system (pp. 291-310). Marcel Dekker, New York. https://doi.org/10.1201/9780203026472.ch18 
Meurer, E. J, Rhenheimer, D., \& Bissani, C. A. (2004). Fenômeno de sorção em solos. In J. E. Meurer (Ed.). Fundamentos de química do solo (2nd ed., pp. 131-179). Porto Alegre: Gênesis.

Neis, L., Paulino, H. B., Souza, E. D., Reis, E. F., \& Pinto, F. A. (2010). Gypsum in management systems and soybean productivity in southwest region of Goiás. Revista Brasileira de Ciência do Solo, 34(2), 409-416. https://doi.org/10.1590/S0100-06832010000200014

Nora, D. D., Amado, T. J. C., Bortolotto, R. P., Ferreira, A. O., Keller, C., \& Kunz, J. (2014). Chemical soil changes and corn yield under gypsum application combined with lime. Magistra, 26(1), 1-10.

Pauletti, V., Pierri, L. de, Ranzan, T., Barth, G., \& Motta, A. C. V. (2014). Long-term effects of the application of gypsum and lime in a no-till system. Revista Brasileira de Ciência do Solo, 38(2), 495-505. https://doi.org/ 10.1590/S0100-06832014000200014

Raij, B. V. (2008). Gesso na agricultura. Campinas: Instituto Agronômico/Fundação IAC.

Rampim, L. (2011). Chemical attributes of a soil and response of wheat and soybean to gypsum in no-tillage system. Revista Brasileira Ciência do Solo, 35(5), 1687-1698. https://doi.org/10.1590/S0100-0683201 1000500023

Reichert, J. M., Kaiser, D. R., Reinert, D. J., \& Riquelme, U. F. B. (2009). Temporal variation of soil physical properties and root growth of black beans in four management systems. Pesquisa Agropecuária Brasileira, 44(3), 310-319. https://doi.org/10.1590/S0100-204X2009000300013

Reichert, J. M., Reinert, D. J., \& Braida, J. A. (2003). Qualidade dos solos e sustentabilidade de sistemas agrícolas. Ciência e Ambiente, 27, 29-48.

Sanchez, E., Genú, A. M., Maggi, M. F., \& Muller, M. L. (2014). Propriedades físicas do solo e produtividade de soja em sucessão a plantas de cobertura de inverno. Revista Magistra, 26(3), 262-271.

Silva, F. A. S., \& Azevedo, C. A. V. (2016). The Assistat Software Version 7.7 and its use in the analysis of experimental data. African Journal of Agricultural Research, 11(39), 3733-3740. https://doi.org/10.5897/ AJAR2016.11522

Soratto, R. P., \& Crusciol, C. A. C. (2008a). Chemical soil attributes as affected by lime and phosphogypsum surface application in a recently established no-tillage system. Revista Brasileira de Ciência do Solo, 32(2), 675-688. https://doi.org/10.1590/S0100-06832008000200022

Soratto, R. P., \& Crusciol, C. A. C. (2008b). Black oat phytomass and nutrient accumulation as affected by surface application of lime and phosphorgypsum during establishment of no-tillage system. Ciência Rural, 38, 928-935. https://doi.org/10.1590/S0103-84782008000400004

Souza, F. R., Rosa Junior, E. J., Fietz, C. R., Bergamin, A. C., Venturoso, L. R., \& Rosa, Y. B. C. J. (2010). Physical attributes and performance of soybean in Oxisol under two management systems. Ciência e Agrotecnologia, 34(6), 1357-1364. https://doi.org/10.1590/S1413-70542010000600001

Zambrosi, F. C. B., Alleoni, L. R. F., \& Caires, E. F. (2007a). Gypsum application and ionic speciation of the solution from an Oxisol under no-till system. Ciência Rural, 37(1), 110-117. https://doi.org/10.1590/S010384782007000100018

Zambrosi, F. C. B., Alleoni, L. R. F., \& Caires, E. F. (2007b). Nutrient concentration in soil water extracts and soybean nutrition in response to lime and gypsum applications to an acid Oxisol under no-till system. Nutrient Cycling in Agroecosystems, 79(2), 169-179. https://doi.org/10.1007/s10705-007-9105-7

Zandoná, R. R., Beutler, A. N., Burg, G. M., Barreto, C. F., \& Schmidt, M. R. (2015). Gypsum and lime increase soybean and maize yield and decrease drought stress. Pesquisa Agropecuária Tropical, 45(2), 128-137.

Zhang, X. C., \& Norton, L. D. (2002). Effect of exchangeable Mg on saturated hydraulic conductivity, disaggregation and clay dispersion of disturbed soils. Journal Hydrology, 260(1-4), 194-205. https://doi.org/ 10.1016/S0022-1694(01)00612-6

\section{Copyrights}

Copyright for this article is retained by the author(s), with first publication rights granted to the journal.

This is an open-access article distributed under the terms and conditions of the Creative Commons Attribution license (http://creativecommons.org/licenses/by/4.0/). 